Breda MIHELIČ

\section{Maks Fabiani and urbanism in Vienna at the turn of the $19^{\text {th }}$ century}

\section{Urban planning at the turn of the $19^{\text {th }}$ century: ideological background}

In the $19^{\text {th }}$ and the $20^{\text {th }}$ century, two types of spatial projections regarding the development of future cities evolved. In her book Urbanisme, utopies et réalités ${ }^{[1]}$ (Choay, 1965), F. Choay named them the progressist and culturalist model. Each one had its own concept and ideas regarding the future of city development.

The progressist model was based on the utopian socialist ideas from the beginning of the $19^{\text {th }}$ century. Among the proponents of these ideas were Robert Owen, Charles Fourier, Benjamin Richardson, Etienne Cabet, Pierre Joseph Proudhon and others. At the end of the $19^{\text {th }}$ century, Otto Wagner developed progressist ideas in his proposal of the Great City (Die Grossstadt) ${ }^{[2]}$, while at beginning of the $20^{\text {th }}$ century another proponent of the progressive models were Tony Garnier in his proposal for an industrial city (Cité industrielle) ${ }^{[3]}$, and later, in the 1920 's, the international movement C.I.A.M. with their proposal for a functional city, formulated in The Athens Charter ${ }^{[4]}$ by Le Corbusier.

\section{Otto Wagner and a progressist model of urban growth}

The proponents of this model based their ideas on the concept of a universal man with universal needs. They believed in the future, in science and technology, in the idea of progress which was supposed to solve all the ills associated with cities. Progressist ideas are thus reflected in the functional organization of a city and its design. The proponents of the progressist model propose a new urban order, suitable for any human society at any given time and space. They were convinced that a type apartment is appropriate for this new order, the uninhibited growth of a city and an urban form, open towards the countryside. This form is organised and distributed in accordance with the basic urban functions (residence, work, recreation and traffic). A progressist city rejects and doesn't pay attention to the historical heritage issues. It is subject only to the very clear logic of geometrical laws.

The most typical Viennese representative of the progressist urban planning at the end of the $19^{\text {th }}$ century was Otto Wagner, as his essay Die Grossstadt proves. Wagner believed in a universal man with universal needs, which are essential for the organization and design of a city. As he wrote on several occasions, he was convinced that any artistic creation has to originate from set goals, needs, means and characteristics of the actual time. His motto 'Artis sola domina necessitas' (Only needs rule art) corresponds to this assumption. Wagner claimed that typical needs necessarily call for typical architectural forms, for anonymous architecture and even uniformity on a city level. As an example he designed the urban plan for the $22^{\text {th }}$ Viennese district. Its urban form consists of a rectangular grid of uniform buildings, parks, obelisks, monuments, fountains and public palaces, interconnected with a good traffic network. The design was based on the functionality principle, which Wagner advocated in the architecture also. So he showed how the morphology of a historical city centre can be adapted to the transformed needs of a metropolis' growth.

For Wagner the only adequate future for a city was the Great City (Die Grossstadt), which was 'the most modern architec-

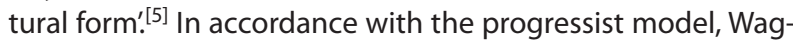
ner proposed an unlimited growth. He designed a city as a federation of autonomous districts (Bezirk), equipped with all the necessary services and interconnected with a network of circular boulevards and radial avenues. Wagner proposed a functional reorganization of the city. Instead of the traditional zoning, he advocated the intertwining of urban functions, which would among other things reduce traffic. Wagner promoted the idea of decentralised concentration, a modern concept, which is in today in the focus of present theories regarding the sustainable development of cities.

Wagner devised a modular city, where every module or district lives its own independent life, while operating as an integral part of the urban structure as a whole all in sync with each other.

\section{Camillo Sitte and a culturalist model of urban growth}

The second, culturalist or conservation model arises from the works by John Ruskin and William Morris ${ }^{[6]}$ and their criticism regarding industrial cities. Nevertheless, we have to look for the real origin of this model, those of the romantic writers (Victor Hugo, J. Michelet) and their nostalgic idea of 'the lost beauty'. Other influences were historical and archaeological studies. Unlike a progressist city, a culturalist urban form is spatially limited and completely separated from the nature that surrounding it. Culturalist cities are rather small, the same as cities in the middle ages. Within them, we can't find any trace of geometry or prototype forms. What is emphasised is the notion of a community and a sense of collective spirit. The predominant idea is anti-industrialism. While for the progressists, hygiene is of key importance, the culturalists' main focus was the aesthetic. Ruskin is convinced that all artistic creations have to originate from nature. He argues for the use of traditional materials, such as wood or stone, and says that even new techniques need to be built manually and not industrial. The use of industrially produced metallic constructions for him is a violation of the principles of nature. Ruskin proposes a return to a concept of art, inspired by the middle ages (Ruskin, 1848).

Two most important representatives of the culturalist model at the end of the $19^{\text {th }}$ century were Ebenzar Howard and Camillo Sitte. Howard profoundly influenced the urban planning culture at the break of the $19^{\text {th }}$ and the $20^{\text {th }}$ century with 
his idea of garden cities, developed in the book entitled Tomorrow, a Peaceful Path to Real Reform, ${ }^{[7]}$ published in 1898. At the end of the $19^{\text {th }}$ century, the idea regarding garden cities was especially popular in the Anglo-Saxon countries, where it was considered as the best cure for over-populated cities.

Camillo Sitte (1843-1903), the author of the book entitled City Planning According to Artistic Principles (1889) ${ }^{[8]}$ had a crucial influence mainly on the urban planning culture in Central Europe. Since the process of urbanization in this geographical area was slower than in the West European countries, the idea of garden cities and de-urbanization didn't have many proponents in Central Europe.

Sitte, an architect and art historian was very interested in history, as he proved in his book discussing the systematic morphological analysis of medieval and renaissance towns and squares. He wrote that such analyses can contribute to better solutions for the present problems encountered while building cities. He claimed that modern urban planning should meet three fundamental conditions: to break away with the tradition of building houses in rows; to preserve old towns as much as possible; and to make new creations according to the ideal of the antique models. Sitte used these morphological analyses of three-dimensional urban spaces, in both a ground plan and in volume as a basis for his three elementary principles of urban design, which should serve modern urbanism: the principle of harmony between public buildings and their surroundings; the principle of designing vibrant urban ambiences; and the principle of arrangement and reconciliation. Due to his conservationist ideas, Sitte was considered the founder and initiator of the protection of monuments.

But Sitte wasn't only a mere critic of the aesthetic side of modern cities building. He was also aware of the need for urban regeneration and adaptation to the demands of modern life.

"Modern life and modern construction techniques don't allow the imitation of old town organizations. This is a fact we can't escape without sinking into fruitless fantasies. Beautiful and perfect monuments of the old masters have to be preserved differently, not only with foolish reproduction. We might reap a new harvest from the seemingly barren soil only, if we research and find the essence of regulation and succeed to implement our findings in modern conditions" (Sitte, 1889: 74)

Sitte's ideas had an important influence on the urban planning of the second half of the $20^{\text {th }}$ century. In the 1970's, Sitte was even considered to be the father of post-modernism ${ }^{[9]}$. His popularity reached its pinnacle in the last decades of the $20^{\text {th }}$ century with the movement for new urbanism, ${ }^{[10]}$ whose members sited Sitte's work as one of their major historical references.

Otto Wagner and Camillo Sitte were considered as the then two pillars of Viennese urban planning. We could say that their ideas somehow express the dialogue between modernity and historical memory. Both men were architects and engineers, unlike the majority of urban planners. Hence they could design a city in three dimensions. Their architectural education was expressed in a strong interest for the beauty of a city, which they understood differently. Sitte thought that the beauty of a city was connected to art, in its noblest meaning of the word; a harmony, which seduces our senses. Wagner on the other hand thought that the beauty of a city is in allowing room for modern city forms, in providing good living and working conditions and to comply with the functional, hygienic and existential needs of modern man. His opinion was that the beauty of a city doesn't spring forth from a harmonic combination of heterogenic elements, but from the effect created by discreet elements, united in one big monumental form. Wagner was convinced that modern eyes lost the feeling to intimate scale and adjusted themselves to more monotonous images, to straight lines and huge masses.

Interestingly, Sitte never designed any great city neither was Wagner's utopian metropolis ever realised.

\section{Max Fabiani: between the progessism of Wagner and culturalism of Sitte}

Fabiani's work remained hidden in Sitte's and Wagner's shadow for a long time, despite the good reputation he had in cultural circles of modern Vienna at the turn of the $19^{\text {th }}$ century. Due to the efforts of the late professor of architectural history at the University of Trieste, Marco Pozzeto, Fabiani's work is now well-known and is now considered within a Central European context.

Maks Fabiani (Kobdilj, Slovenia 1865 - Gorizia, Italy, 1962), whose father originated form Slovene Karst and mother from Trieste ${ }^{[11]}$, studied architecture at the Vienna University of Technology (1883-1889). Even before his graduation, Fabiani was an assistant at the Graz University of Technology (1889-1891). In 1891 and 1892, he worked as Prof. Wilhelm Edler von Lowe's assistant at the chair of architecture for two urban planning courses: 'Urban planning from antiquity to modern times' and 'Evaluation of artistic principles in modern urban planning.' During this time, he acquainted himself with Camillo Sitte's work and his ideas affected him strongly.

Between 1894 and 1896, Fabiani worked in Otto Wagner's studio in Vienna. He participated in Wagner's project for the metropolitan railway and helped Wagner with his book entitled Modern Architecture ${ }^{[12]}$, for which he wrote several chapters. He described this collaboration in one of his letters to Nace Šumi, PhD, Professor at the Faculty of Arts at the University of Ljubljana in 1952. "You might be interested to know that I wrote the booklet Modern Architecture in the Hutteldorf Villa on Wagner's express wish. The writing occupied us for several weeks. Wagner and I discussed all topics. He completely trusted me, even regarding style and choice of examples ..."[13] Therefore it isn't a coincidence that Fabiani himself advocated the ideas of the Great City (Die Grossstadt), applied them in his work and re-shaped them in his urban plans, such as the regulatory plan for Ljubljana and the regulatory plan for Bielsko.

Between 1896 and 1898, Fabiani worked as an assistant for composition at Prof. Karl König at the Vienna University of 
Technology and was later, in 1898 and 1899, a lecturer of antique architecture at the same university.

Fabiani attained his doctorate in 1902 and became the Emperor's counsellor for architecture and history of art in the same year. Between 1910 and 1917, he worked as a lecturer of ornamental drawing at the Vienna University of Technology, where he was promoted to professor of composition in 1917.

Fabiani was appointed the same year as the head of the Regional Office for the Reconstruction of the Posočje Region. Two years later, in 1919, he gave up his academic career in Vienna and moved to Gorizia, where he devoted himself to the reconstruction of towns and villages, affected by the war. Despite this, he was held in high esteem in Viennese circles even late into his life. At age of 80 , he received a 'Golden Doctorate' by the Vienna University of Technology. Maks Fabiani died in Gorizia in 1962.

Camillo Sitte and Otto Wagner are undoubtedly two of the key figures within the Viennese artistic and intellectual circles at the turn of the $19^{\text {th }}$ century. Much less known is that Maks Fabiani was held in high esteem amongst the most distinguished architects of that time also. Fabiani was very important for the development of the technological sciences (urban planning is one of them), as the chairman of the Austrian Association of Engineers and Architects, Atillia Relle ${ }^{[14]}$ wrote.

It is less known even to larger professional public, that Fabiani was the first of the Vienna architects who chose a thesis on urban planning for his doctorate in the technological sciences. The academic title, awarded to Fabiani, was "the proof of genuine science, which stimulates the moral dimension of researcher" (Pozzetto, 1997: 30). The additional point to this is the request by the teaching staff at the University of Technology, addressed to the Minister of Culture and Education, in which they proposed that Maks Fabiani should become a professor ad personam (without a call for applications). They substantiate their request with the following explanation:

"It would be of great benefit for our university, if we could give a permanent position to Dr. Fabiani and offer him all the possibilities, suitable to his qualities, especially because such qualities are rarely seen in one person ... We would be very honoured if we could invite Maks Fabiani to become a senior university teacher at our Chair of Architecture." (Ibid.).

Fabiani argued for his thesis with two regulation plans, for Ljubljana and Bielsko (now Biala in Poland). The report, accompanying the latter plan, clearly expresses the architect's artistic credo and his reflections upon urban planning: "A city is like a big house. But look! While each of us tries to make the planning scheme for his house as carefully and good as possible and shifts his furniture around his apartment to place it along the walls as effective as possible, almost noone among the thousands of city-dwellers is aware of the fact that a city, our big common apartment, can be arranged well, only if we first find a position for individual buildings, squares, streets and parks. All of this brings great advantages without substantial costs. A city or a town has been always creating an arrangement of residential and hired houses, palaces and so on. Nevertheless, a logically organized city is a new acquisition. This is an undisputable artistic task" (Pozzetto, 1988: 59-60).

For Fabiani, urban planning had a noble artistic mission, but at the same time he was aware that urban planning has to offer functional solutions and that could also eliminate problems regarding hygiene, traffic, industry, green areas and architectonic typology. A city couldn't be seen as a monolith piece of art anymore, but as a living organism, which has to stay receptive to ongoing alterations. Urban planning is therefore a continual process, able to transform all the time. "We keep asking ourselves when are we going to achieve the final solution or when the picture of a city will be completed? Never!" (ibid.: 61) Because a city is a living organism that grows constantly, the same as a person develops from his or her birth onwards. This was a completely novel idea in those times. We don't find it in the works or writings of Sitte, Wagner or other architects of that period.

Architecture, urban planning and planning were for Fabiani only different levels of the same idea. All architecture has to be designed in such way that it is in accordance with its spatial and city environment. If planning is to be successful, it has to deal with a city as a whole and consider how it blends in its territory and region. This principle is the basis for regional planning.

Fabiani had a very acute sense for the local environment. He emphasised the need to respect the local character and to preserve genius loci, which is the most complete expression of the soul of the people and the place. The highest imperative for him was always the respect of the local spirit, as he proved with his architectural and urban plans for Ljubljana and various Italian and Austrian towns. His architecture completely blends with the form and materials of the local environment; it fuses with the town and becomes its integral part of it.

Fabiani is seen as the forefather of the preservation of historical towns. Due to his respect of historical heritage areas, he was appointed secretary of the permanent board for monuments, established in Vienna as a consultative section of the central imperial and royal commission; for the protection of monuments. All Fabiani's essays and blueprints prove that he profoundly appreciated the heritage of historical towns He wrote:

"Every architectural fragment, connected to the history of a town, every sign, even of minor importance, contributes to the enrichment, poetry and dignity of a town. Historians and archaeologists must help architect and provide him with the necessary documents." (Ibid.: 103).

Fabiani first examined his urban planning ideas in his regulation plan for Ljubljana. The city suffered a violent earthquake in 1895. In this disaster, almost 90 percent of buildings were damaged $^{[15]}$, and this opened up the possibility for a radical regeneration of the city. The city council decided to commission a general regulation plan and asked the Association of engineers and architects to name some architects-urban planners, who would be prepare to deal with this task. Among the proposed names mentioned at that time were (Ludwig 
Baumann, Eugen Fassbender, Mayreder brothers, Alfred Reinhold, Leopold Simony, Theodor Bach), the council chose Camillo Sitte, who designed and sent the plan in September the same year. At the same time, Fabiani made his regulation plan for free and on his own initiative and sent it to the municipal authority (Šumi, 1954). Comparative analyses showed that both plans had many things in common and also that Fabiani's plan was more aligned with the character of the city and understood its needs better. Fabiani was the first urban planner with a very clear vision of the development of Ljubljana, which he thoroughly explained in his accompanying report. The text, which was printed in 300 copies as an offprint, is the first Slovene essay on urban planning. With this, Fabiani laid the foundation for urban planning terminology. ${ }^{[16]}$

He designed his plan after a meticulous morphological analysis of the existing city, based upon Sitte's model. This analysis helped him to determine the fixed elements of the existing urban form and the major outlines for its future development. He based the new urban form on a street network, composed of concentric and radial streets. Among these, squares and parks facing Ljubljana castle are placed. The predominant motif is a 28 metres wide and 6400 metres long ring road, which is lined with trees and winds around the city. This boulevard, similar to the Vienna Ringstrasse, complements the existing motif of two streets, enclosing the castle hill along the river banks.

In his urban planning, Fabiani was interested in the shaping of urban form as well as in the functioning and organization of the city. To facilitate the connection among different parts of the city, he conceived a tram line and prepared general guidelines for the construction of the city in 3 dimensions: design of buildings, arrangement of squares and parks; and organisation and the layout of market spaces and other public buildings. Fabiani's plan for Ljubljana is a reflection of both Sitte's conservative urban planning ideas and Wagner's functionalism. He treats the city as a whole and respects the local particularities (genius loci) and in the same times he ensures a good functioning of it. Nevertheless, the most important quality of his plan is that Fabiani foresaw the sustainable development of the city. He designed major outlines, which were the guidelines for the city's development for more than half a century. That he mastered his profession completely only goes to prove an interesting fact that some of his ideas are up-to-date even today.

In his designs for Vienna Karlplatz in $1898^{[17]}$ and Ljubljana Slovenski trg (Slovene Square) in 1899[18], Fabiani carried out the principles of three-dimensional planning on a small scale. His design for Karplatz was awarded the first prize at an invitation of tender, opened by the Vienna Municipality Authority, while the design for the Slovene Square was directly commissioned by the Ljubljana Municipal Council. Both squares are designed from one perspective of sight and also as a monumental set design.

In 1898, the Ljubljana Municipal Council awarded Fabiani the commission for drawing a plan for the expansion of the city north of the railway line ${ }^{[19]}$. Fabiani designed an independent, self-sufficient, well-equipped and organized district according to Wagner's principles of a metropolis. In the centre of the district, he put a big square and drew it three-dimensionally. He used two existing major axes leading to the city centre as its supporting structures and added a third axis, which to connected the city with the cemetery. The secondary street network, composed of radial and concentric streets, shaped as a fan, which narrows towards the city centre. Squares and parks are located at the intersections of the radial and concentric streets: all facing the castle. While Fabiani's regulation plan for Ljubljana from 1895 directed the development of Ljubljana for more than half a century, the plan for the expansion of a city with its geometrical form, which didn't give any consideration to the existing division and ownership of the land, didn't affect the development of the district north of the railway line.

Fabiani's works in Austrian, Italian and Slovene cities and towns are in a way a bridge across these three nations that inhabit the Central European cultural region for almost two millennia. They integrate Wagner's progressivism and Sitte's conservatism, the two main trends in urban planning culture at the end of the $19^{\text {th }}$ century. At the same time, they are a proof of the polivalency of this architect, who mastered several professions: from architecture to urban and regional planning; from the regeneration of cities and towns to constructing waterways between the Adriatic Sea and the Danube river; from philosophy (Akme) to art; from literature to technology. Pozzeto was right when he wrote that Fabiani was "an urban planner by profession, an architect and a civil engineer by education, an artist by his sensitivity and a 'Central European' by culture."

\section{Conclusion}

The $19^{\text {th }}$ century urban planning saw solutions for city problems in new forms in relation to the growth and development of cities and also in new ways of adapting to the demands of modern life. Nevertheless, it didn't change the basic structure of the city, despite all the efforts involved in the search for the new solutions. While the proponents of the culturalist model borrowed their formal language from the middle-ages and the renaissance period, progressive urban planners used the formal language of the baroque and the neo-classical period with straight avenues, lined with uniform building, great vistas, geometrical formalism, parks, etc. Art nouveau, which radically regenerated architecture and applied arts at the turn of the $19^{\text {th }}$ century, didn't influence urban planning in the sense of inventing a new urban form. Urban planning therefore tried to cope with new conditions, created by industrial revolution and new towns' population with traditional urban forms, like streets, squares and parks and particularly with new architecture.

\section{Dr. Breda Mihelič, Art Historian, Docent \\ Urban Planning Institute of the Republic of Slovenia}

E-mail: breda.mihelic@uirs.si

Notes

[1] Choay, F. (1965) Urbanisme; utopies et réalités, Paris, Seuil.

[2] Wagner, O. ((1911) Die Grossstadt, Eine Studie über Diese, Vienna.

[3] Garnier, T. (1917) Une Cité Industrielle: étude pour la construction des villes. Paris. 
[4] Le Corbusier (1957) La charte d'Athènes. Paris, Minuit.

[5] Banik Schweitzer, R. (1999) Urban Visions, Plans and projects, 1890-1937, in: Blau, E., Platzer, M. (eds.) Shaping the Great City: Modern Architecture in Central Europe 1890-1937, p. 62. Munich, London, New York, Prestel Verlag.

[6] John Ruskin and William Morris were typical opponents to the industrial development. In 1877 William Morris founded the Society for the Protection of Ancient Buildings, which indirectly influenced the creation of the later National Trusts, the most important British non governmental organisation for the protection of monuments in GB.

[7] Howard, E. (1898) Tomorrow, a Peaceful Path to Real Reform. London.

[8] Sitte, C. (1889) Städte Bau nach seinen Künstlerischen Grundsätzen. Vienna.

[9] Jencks, C. (1977) The Language of Post-Modern Architecture. New York, Rizzoli.

[10] Duany, A., Plater-Zyberk, E. (1991) Towns and town making principles. Cambridge, Mass: Harvard University Graduate School of Design.

[11] In the letter to Marjan Mušič Fabiani says that one third of his blood is Slovene, in: Pozzetto, M. (1997) Maks Fabiani - vizije prostora. Kranj, Libra.

[12] Wagner, O. (1895) Moderne Architektur, Vienna

[13] Nace Šumi published this letter in the Art History Journal, Ljubljana, 1991, pp. 121-122.

[14] Relle, A. (1899) Die Assanierung der Städte in Österreich-Ungarn, in: Zeitschrift des Österreichischen Ingenieur- und Architekten Vereins, Vienna.

[15] In the memorial book Ljubljana 1895-1910, edited by Fran Govekar and Miljutin Zarnik and published by the Municipality of Ljubljana in 1905 , one can read that $10,3 \%$ of buidings had to be demolished after the earthquake and that almost all other buildings had to be repaired.

[16] Fabiani, M. (1895) Regulacija deželnega stolnega mesta Ljubljane. Dunaj; german edition: Fabiani, M. (1895) Erläuterungs-Bericht zum Entwurfe eines General-Regulierungs-Planes der Stadt Laibach. Wien.

[17] Die Concurrenz für die Ausgestaltung des Karlskirchenplatzes, Wiener Bauindustrie Zeitung, 1898, pp. 185-187.

[18] The project was published in the magazine Der Architekt, 1900/6, p. 29.

[19] Fabiani, M. (1899) Pojasnilo k načrtu za osnovo in preosnovo severnega dela mesta. Dunaj.

\section{References}

Blau, E., Platzer, M. (eds.) (1999) Shaping the Great City: Modern Architecture in Central Europe 1890-1937. Munich, London, New York, Prestel verlag.

Choay, F. (1965) Urbanisme; utopies et réalités. Paris, Seuil.

Donnachie, I. (2000) Robert Owen. Owen of New Lanark and New Harmony. Tuckwell Press.

Duany, A., Plater-Zyberk, E. (1990) Towns and town making principles. Cambridge, Mass: Harvard University Graduate School of Design.

Fabiani, M. (1895) Regulacija deželnega stolnega mesta Ljubljane. Dunaj; nemška izdaja: Fabiani, M. (1895) Erläuterungs-Bericht zum Entwurfe eines GeneralRegulierungs-Planes der Stadt Laibach. Wien.

Fabiani, M. (1899) Pojasnilo k načrtu za osnovo in preosnovo severnega dela mesta. Dunaj.

Fabiani, M. (1899) Regulierung der Stadt Bielitz-Erläuterunngsbericht zur General-Regulierung Plane der Stadt Bielitz. Wien.

Garnier, T. (1988) Une Cité Industrielle: étude pour la construction des villes. Paris, P. Sers.

Howard, E. (1898) Tommorrow, a Piecefull Path to Real Reform. London. Jencks, C. (1977) The Language of Post-Modern Architecture. Rizzoli, New York.
Le Corbusier (1957) La charte d'Athènes. Paris, Éditions de Minuit.

Manuel, F., Fritzie, M. (1979) Utopian Thought in the Western World. Cambridge, Mass., Belknap Press.

Pozzetto, M. (1983) Maks Fabiani 1865-1962: Ein Architekt der monarchie. Wien, Edition Tusch

Pozzetto, M. (1997) Maks Fabiani - vizije prostora. Kranj, Libra.

Pozzetto, M. (ed.) (1988) Maks Fabiani. O kulturi mest: spisi 1895-1960. Trst, Založništvo tržaškega tiska.

Ruskin, J. (1981) The Stones of Venice. Boston, Little Brown.

Sitte, C. (1997) Umetnost graditve mest. Ljubljana, Habitat, d.o.o.

Šumi, N. (1954) Arhitektura secesijske dobe v Ljubljani. Ljubljana, Mestni muzej.

\section{Mojca ŠAŠEK DIVJAK}

\section{Urban planning for the strategic spatial development of Ljubljana}

\section{Introduction}

\subsection{City planning of Ljubljana in the past}

The beginnings of modern city planning of Ljubljana date back to the period after the earthquake in 1895 when Ljubljana was a provincial centre in the Austro-Hungarian Monarchy and had 36,000 inhabitants. In the period of reconstruction the municipality council invited the Vienna architect Camillo Sitte to carry out a general regulation plan for Ljubljana. Max Fabiani, Slovenian architect, also proposed his plan on his own initiative. Both architects were members of the Vienna cultural circle but belonged to different urbanistic orientations. Sitte defended the cultural tradition and was not in favour of geometrically regular shapes of new towns with the 'American' road grid. He envisaged Ljubljana's development for the next fifty years in the same area within the limits of the southern railway. Fabiani was more advanced and boldly treated series of problems concerning the city's development, its organisation, traffic regulation and its shape. $\mathrm{He}$ also presented to the municipality a regulation plan for the northern part of Ljubljana (today the southern Bežigrad). That period was a turning point in planning and construction of the city and its development became the topic of open discussions in Ljubljana for the first time.

After the Monarchy's break-up the role of Ljubljana increased, it became the administrative, political and cultural centre of Slovenia. Thirty years after Fabiani's proposal of a city ring, Plečnik added a new broader ring beyond the city centre to the plan of Greater Ljubljana, which also included nearer villages and settlements. Plečnik devised Ljubljana as a concentric city, spreading radially from the centre outwards. Nevertheless, his concept of the regulation of Ljubljana and 